Nigerian Journal of Environmental Sciences and Technology (NIJEST)

www.nijest.com

ISSN (Print): 2734-259X ｜ＩSSN (electronic): 2734-2603

Vol 5, No. 1 March 2021, pp 234 - 239

\title{
Bacteriological Assessment of Palms of Students of Delta State University, Abraka
}

\author{
Jemikalajah D. J. ${ }^{1}$ Enwa F. O. ${ }^{2, *}$ and Etaoghene A. D. ${ }^{2}$ \\ ${ }^{1}$ Department of Microbiology, Faculty of Science, Delta State University, Abraka, Nigeria \\ ${ }^{2}$ Department of Pharmaceutical Microbiology \& Biotechnology, Faculty of Pharmacy, Delta State University, \\ Abraka, Nigeria \\ Corresponding Author: *felixenwa@delsu.edu.ng
}

https://doi.org/10.36263/nijest.2021.01.0276

\begin{abstract}
The bacteriological assessment of palms of students of Delta state University Abraka, was undertaken. A total of hundred samples were collected using a sterile swab sticks. Streak plate method was used and also biochemical test carried out following standard procedures. Results showed growth on ninety-three (93) cultured plates (93\%). Bacteria isolates identified were Staphylococcus aureus, Escherichia coli, Proteus sp., Streptococcus sp, Bacillus sp., Salmonella sp. and Klebsiella. Staphylococcus aureus had the highest prevalence of $41 \%$ while, Salmonella sp (1\%) was the least prevalent. Results also showed that female students had a higher incidence of bacterial load (58\%) compared to the male students (42\%), There is therefore a need to create awareness among students on good hand hygiene practices since the hand is a major reservoir of pathogenic organisms.
\end{abstract}

Keywords: Bacteria, Palms, hygiene, Staphylococcus aureus, Escherichia coli, Abraka

\subsection{Introduction}

The hand is the extremity of the superior limb, hence, serves as a medium for the transfer of microorganisms from one location to the other and from one person to another (Hammond et al., 2000). "According to the US Centre for Disease Control and Prevention and the Association for Professionals in Infection Control and Epidemiology, simple hand washing is the single most important and effective method of preventing the spread of transmissible disease" (Burton et al., 2011). Human hands usually harbour microorganisms both as part of normal micro flora and microorganisms contacted from the environment. These normal microfloras such as Staphylococcusaureus resident in the human skin and can therefore be passed from one individual to another. Other pathogen that may be present on the hand as transient types includes Salmonella spp., Shigella spp., Escherichiacoli (Curtis and Cairncross, 2003). The high incidence of diarrheal diseases and other communicable disease among students are actually due to poor knowledge and practice of personal and environmental hygiene (Strina et al., 2002). Poor knowledge and practice of, and attitudes to personal hygiene, such as hand washing, has negative consequences for a child's long term overall development. Good hand washing practice is therefore a prerequisite to a child's survival (Lopez-Quintero et al., 2009). Infectious transmission through contaminated hands among students is a common pattern seen in higher institutions and failure to perform appropriate hand hygiene practices has been recognized as a significant contributor to outbreaks of infectious diseases by the world health organization (WHO, 2009). Hand washing is critical in this era of covid-19 where human to human transmission is mainly through respiratory droplets from infected individuals, contact with contaminated objects and surfaces, social activities like hand-shaking, hugging and kissing (Imai et al., 2020; Majumdar and Mandl, 2020).This study is thus designed to determine the bacterial load on the palms of university students to assess whether they carry pathogenic bacteria that could cause an infection to these students and the level of adherence of students to proper hygiene especially hand washing. 


\subsection{Materials and Methods}

\subsection{Study area}

This research was carried out among students in different faculties in campus 3 of Delta State University Abraka. Abraka is lies on longitude $5.7917^{\circ} \mathrm{N}$ and latitude $6.0987^{\circ} \mathrm{E}$ with a student population of 22,000 (undergraduate) located in the South-South geopolitical zone of Nigeria (Figure 1). It is an urban town with the major occupation of farming, trading, civil servants and students (DELSU, 2019/2020).

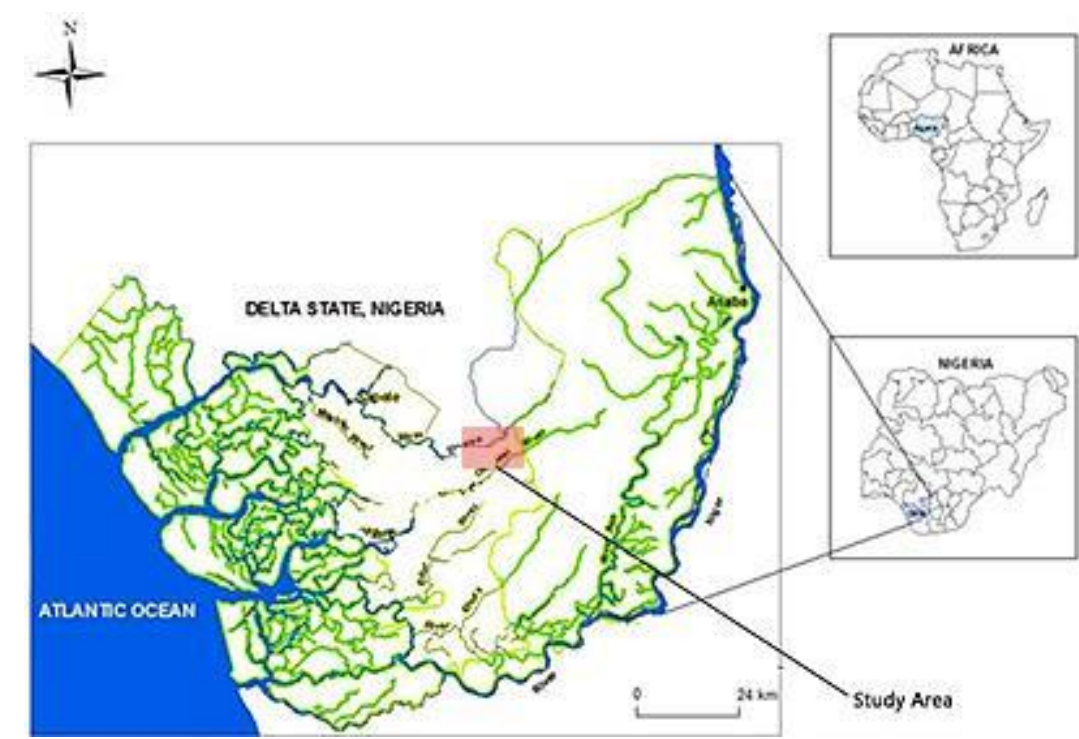

Figure 1: Map of Delta State Nigeria showing location of study area Source: Irwin and Oghenevwede (2014)

\subsection{Study population}

This study enrolled a total of 100 students made up of 50 males and 50 females. Ten (10) students each were randomly selected from each of the faculties on campus 3 .

\subsection{Sample collection}

With the aid of sterile swab sticks, Hundred (100) samples were collected from students. Each swab stick was introduced into $2-3 \mathrm{mls}$ of peptone water in sterile sample bottles. The hand swabs were properly closed and transported to the Microbiology Laboratory Delta State University, Abraka for analysis.

\subsection{Media preparation and culture}

The media used were MacConkey agar and Nutrient agar which was weighed according to manufacturer's instruction and was sterilized at $121^{\circ} \mathrm{C}$ by autoclaving for 15 minutes. Blood agar was prepared by removing $50 \mathrm{mls}$ of molten nutrient agar and replaced with $50 \mathrm{mls}$ of sheep blood to give $5 \%$ blood agar. Samples were culture by streak plate method and incubated at $37^{\circ} \mathrm{C}$ for 24 hours.

\subsection{Biochemical identification of isolates}

Isolated microbes were characterized and identified based on colony morphology, cultural appearance and biochemical tests (Cowan and Steel, 1974; Cruishank et al., 1975; Sanders, 1994).

\subsection{Gram staining}

The developed bacteria colonies after 24 hours of incubation was Gram stained and examined for Gram positive and negative bacteria. 


\subsection{Catalase test}

This test was done to differentiate Staphylococcus and streptococcus. Few drops of hydrogen peroxide solution were placed on a glass slide and an applicator stick was used to emulsify the suspected colonies of the test organism and observed for bubbles. Staphylococcus was positive and streptococcus negative.

\subsection{Motility test}

Motility was performed on all isolated bacteria. Semi-solid agar was prepared and stabbed with the isolates to the bottom of the tube and incubated at $37^{\circ} \mathrm{c}$ for 24 hours. The swarming of bacteria in the medium is positive for motile bacteria.

\subsection{Oxidase test}

Three drops of oxidase reagent (tetra-methyl-p-phenylenediaminedihydrochloride) was added on a filter paper. Colony of the test organism was picked, smeared on the filter paper and observed for development of a blue purple colour within 10 seconds. The formation of purple color indicates a positive result.

\subsection{Indole test}

Indole test demonstrate the ability of certain bacteria to decompose the amino acid called tryptophan to indole that accumulate in the medium (tryptone water). The test organism was inoculated in the medium and incubated at $37^{\circ} \mathrm{C}$ for 24 hours. Then $0.5 \mathrm{ml}$ of Kovac's reagent was added and gently shaken formation of pink to red ring color on top of the medium indicates a positive results.

\subsection{Citrate test}

Some Gram negative bacteria utilize citrate and change Simmon's Citrate Agar medium to blue. The slants agar were streaked with a suspension of the test organisms and incubated at $37{ }^{\circ} \mathrm{C}$ for 24 hours. Blue colouration indicates positive.

\subsection{Urease test}

The test demonstrate the ability of some Gram negative bacteria that produces the enzyme urease which breakdown urea. Urea agar was prepared according to manufacturer's instruction and $2 \mathrm{mls}$ was dispensed into bijou bottles to form a slant. It was inoculated with isolated colonies, incubated at $37^{\circ} \mathrm{C}$ for 12 hours. A colour change from light orange to pink indicates the production of urease enzyme (positive). No colour change indicates negative.

\subsection{Coagulase test}

This test differentiates coagulase positive bacteria like Staphylococcus aureus from coagulase negative Staphylococcus epidermidis when human citrated plasma was tested with isolated colonies. The enzyme coagulase produced by Staphylococcus aureus react with the plasma and form clot.

\subsection{Results}

Our result shows that out of the 100 samples examined, a total of ninety-three (93) isolates were obtained. Eight (8) different bacterial species were identified from the total number of samples investigated. Among the bacterial species identified after biochemical characterization includes Staphyloccocusaureus, Escherichia coli, Proteus sp, Streptoccocus sp, Bacillus sp, Salmonella sp, and Klebsiella sp (Table 1).

The bacterial species observed in this study such as, Staphyloccocus aureus, Bacillus sp., Klebsiella sp., and Escherichia coli were however similar to the findings of Bellissimo-Rodrigues et al. (2017). Staphyloccocus aureus was seen to have the highest prevalence. The findings of these bacteria are in agreement with the work of Bellissimo-Rodrigues et al. (2017). This may be attributed to the presence of some pathogenic bacteria that are spread by contaminated hands especially the carriers of Staphyloccocus aureus in their nostrils and faecal contamination of palms with enterobacteriaceae. These bacteria are passed to other students by hand shake, hugging and eating together as earlier 
opined by Lax and Smith (2014) and Mathieu et al. (2013). Washing of hand has great impact on reducing the burden of infections in the developing world. In this study, the practice of hand washing among the students is very poor with respect to reported studies from other countries.

Table 1: Biochemical identification of bacterial isolates

\begin{tabular}{|c|c|c|c|c|c|c|c|c|}
\hline $\begin{array}{l}\text { Gram } \\
\text { stain }\end{array}$ & Shape & Catalase & Coagulase & Motility & Indole & Urease & Citrate & Bacteria \\
\hline+ & Cocci & + & + & - & - & - & + & Staphylococcus aureus. \\
\hline- & Bacilli & - & - & + & + & - & - & Escherichi coli \\
\hline- & Bacilli & - & - & + & - & + & + & Proteus sp. \\
\hline+ & Cocci & - & - & - & - & - & + & Streptococcus sp. \\
\hline+ & Bacilli & + & - & + & - & - & + & Bacillus sp. \\
\hline - & Bacilli & + & - & + & - & - & - & Salmonella sp. \\
\hline - & Bacilli & + & - & - & - & + & - & Klebsiella sp. \\
\hline
\end{tabular}

Table 2 shows the prevalence of bacterial isolates from the sample examined. Staphylococcus aureus had the highest prevalence rate of $44.1 \%$ followed by Escherichia coli $15.1 \%$ and the least Salmonella sp. $1.1 \%$. This is not alarming because these organisms are predominant as carriers in humans and causes harm only when the infectious dose is high enough to induce an infection. In spite of this, effective hand washing is important in infection control. Appropriate hand washing is the most vital way to reducing the spread of communicable diseases and an intervention that can break the chain of food poisoning and respiratory infection such as covid-19 as observed by Uneke et al. (2014).

Table 2: Bacterial isolates from palm of students

\begin{tabular}{lllll}
\hline Bacterial isolates & No.of samples & $\begin{array}{l}\text { No. (\%) positive for } \\
\text { palm isolates }\end{array}$ & $\begin{array}{l}\text { No. (\%) negative for } \\
\text { palm isolates }\end{array}$ & Prevalence \\
\hline Staphylococcus aureus & 100 & $41(0.41)$ & $52(0.52)$ & 44.1 \\
Escherichia coli & 100 & $14(0.14)$ & $79(0.79)$ & 15.1 \\
Bacillus sp. & 100 & $19(0.19)$ & $74(0.74)$ & 11.1 \\
Proteus sp. & 100 & $7(0.7)$ & $86(0.86)$ & 7.5 \\
Streptococcus sp. & 100 & $6(0.6)$ & $87(0.87)$ & 8.0 \\
Salmonella sp. & 100 & $1(0.1)$ & $92(0.92)$ & 1.1 \\
Klebsiella sp. & 100 & $5(0.5)$ & $88(0.88)$ & 5.4 \\
Total & & 93 & & 100 \\
\hline
\end{tabular}

Table 3 shows the percentage prevalence rate of bacterial isolates that occurred in both male and female students. It was observed that females had more bacteria load of about $54 \%$ when compared to the males having about 39\% bacterial load. Out of the bacteria species identified Staphylococcus aureus were the most predominant and highest in females with relatively low prevalence rate of about $15 \%$ in males. There was thus an increase in the prevalence rate of Bacillus species of about $11 \%$ when compared to females $(8 \%)$.

The human hands naturally harbors microorganisms both as part of a person's normal microbial flora as well as transient microbes acquired from the environment (Curtis et al., 2009). This study shows that over $93 \%$ of all students hands were contaminated with bacteria pathogens. This agrees with the findings of Kenneth et al., (2018) who reported that about 95\% of bacterial load from hands of pupils in their study. This could be an indication of poor personal hygiene practices particularly to maintaining good hand washing practices as stated in a health report by the WHO, (2009). This work further shows that bacterial palm carriage was 58\% higher in the female students than $42 \%$ recorded among the male students. This differs from the findings of Vishwanath et al. (2019) who reported a higher prevalence in male than in female in their study. This could be as a result of age differences and the subjects recruited into current work since their research was carried out among primary school pupils and ours was among university students. However, the high percentage prevalence obtained among female and male students may due to poor hygiene in the school environment because most higher institutions in the developing countries lacks hand washing facilities and where available, they 
may be poorly located, no hand washing materials and in accessibility to students even in this era of covid-19 where hand washing practices is key to reducing transmission of the virus.

Table 3: Bacteria isolates from male and female palm

\begin{tabular}{lllll}
\hline Bacterial isolates & $\begin{array}{l}\text { No. (\%) positive for } \\
\text { palm isolates (male) }\end{array}$ & $\begin{array}{l}\text { No. (\%) negative for } \\
\text { palm isolates (male) }\end{array}$ & $\begin{array}{l}\text { No. (\%) positive for } \\
\text { palm isolates (Female) }\end{array}$ & $\begin{array}{l}\text { No. (\%) negative for } \\
\text { palm isolates (Female) }\end{array}$ \\
\hline $\begin{array}{l}\text { Staphylococcus } \\
\text { aureus }\end{array}$ & $15(0.15)$ & $78(0.78)$ & $26(0.26)$ & $67(0.67)$ \\
Escherichia coli & $8(0.8)$ & & & \\
Bacillus sp. & $11(0.11)$ & $85(0.85)$ & $7(0.7)$ & $86(0.86)$ \\
Proteus sp. & $2(0.2)$ & $82(0.82)$ & $8(0.8)$ & $85(0.85)$ \\
Streptococcus sp. & $0(0.0)$ & $91(0.91)$ & $5(0.5)$ & $88(0.88)$ \\
Salmonella sp. & $1(0.1)$ & $93(0.93)$ & $6(0.6)$ & $87(0.87)$ \\
Klebsiella sp. & $3(0.3)$ & $92(0.92)$ & $0(0.0)$ & $93(0.93)$ \\
& & $90(0.90)$ & $2(0.20)$ & $91(0.91)$ \\
Total & & & 93 \\
\hline
\end{tabular}

\subsection{Conclusions}

The present study shows that the palms of university students harbor a variety of pathogenic organisms which could cause serious infectious diseases like gastro-intestinal infection which are possibly fatal if not attended to. Lack of proper hand washing model, basic hand washing material like soap and water, and the presence of hand sinks at various locations within the university premises were among the reasons for failures of students to adhere to hand washing practices. Provision of these materials can bridge the gap between proper hand washing techniques and the spread of diseases.

\section{Conflict of interest}

All authors declares no conflict of interest

\section{References}

Bellissimo-Rodrigues, F., Pires, D., Soule, H., Gayet-Ageron, A., Pittet, D., (2017). Assessing the likelihood of hand-to-hand cross-transmission of bacteria: an experimental study. Infection Control Hospital Epidemiology, 38, pp. 553-558.

Burton, M., Cobb, E., Donachie, P., Judah, G., Curtis, V. and Schmidt, W.P. (2011). The effect of handwashing with water or soap on bacterial contamination of hands. International Journal of Environmental Research and Public Health, 8(1), pp. 97-104.

Cowan, S.T. and Steel, K.J. (1974). Identification of Medical Bacterial $2^{\text {nd }}$ edition, Cambridge University Press, (London). pp.46-81.

Cruishank, R., Duguid, J.P. and Mamion, B.P. (1975). Medical Microbiology. Vol.2 $12^{\text {th }}$ edition, Churchill Livingstone, pp. 428-434.

Curtis, V. and Cairncross, S. (2003) Effect of washing hands with soap on diarrhea risk in the community: A systematic review. Lancet Infection Disinfection, 3, pp. 275-281.

Curtis, V., Danquah, L. O. and Aunger, R. V. (2009). Planned, motivated and habitual hygiene behaviour: An eleven country review. Health Education Research, 24(4), pp. 655-673.

Delta State University (2019/2020). Delta State University,Abraka, Nigeria. History. https//www.delsu.edu.ng> history. Retreived.

Hammond, B., Ali, Y., Fendler, E., Dolan, M. and Donovan, S. (2000). Effect of hand sanitizer use on elementary school absenteeism. American Journal of Infection Control, 28, pp. 340-346.

Imai, N., Cori, A. and Dorigatti, I. (2020). Transmissibility of 2019nCoV. https:www.imperial.ac.uk/mrcglobal-infectious-diseaseanalysis/news - wuhancronavirus/last (Accessed 2020) 
Irwin, A. A. and Oghenevwede, E. (2014) International Journal of Water Resources and Environmental Engineering. 6(1), pp. 19-31.

Kenneth, A., Hamady, M., Lauber, C.L. and Knight, R. 2018. The influence of sex, handedness, and washing on the diversity of hand surface bacteria. Proceedings of National Academic Science United State of America, 105, pp. 17994-17999.

Lax, S. and Smith, P. (2014). Longitudinal analysis of microbial interaction between humans and the environment. Science magazine, 345, p. 1048

Lopez-Quintero, C., Freeman, P. and Neumark, Y. (2009). Hand washing among school children in Bogata, Colombia. American Journal of Public Health, 99(1), pp. 94-101. https://doi.org/10.2105/AJPH.2007.129759

Majumdar, M. and Mandl, K. (2020). Early transmissibility assessment of a novel coronavirus in Wuhan, China. Preprint. https://papers.ssrn.com/soI3/papers.cfm?abstract id3524675. Last accessed 2020

Mathieu, A., Delmont, T. and Voget, T. (2013). Life on human surfaces: Skin metagenomics. Public Library of science 8(6), e65288.

Sanders, C.C. (1994). Identification of medically important bacteria.Clinical microbiology. Miles, Inc; $3^{\text {rd }}$ edition, pp. 17-18.

Strina, A. S., Cairncross, M. L., Larrea, C. B. and Prado, M. S. (2002). Childhood diarrhoea and observed hygiene behaviour in Salvodor, Brazil. American Journal of Epidemiology, 157, pp. 10321038.

Uneke, C.I., Ndukwe, C.D. and Oyibo, P.G. (2014). Promotion of hand hygiene strengthening initiative in a Nigeria teaching hospital: Implication for improved patient safety in low income health facilities. The Brazillian Journal infections Diseases, 18(1), pp. 21-27.

Vishwanath, R., Selvabai, A.P. and Shanmugam, P. (2019). Detection of bacterial pathogens in the hands of rural school children across different age groups and emphasizing the importance of hand wash. Journal of prevalence medical hygiene, 60(2), pp. 103-108.

World Health Organization, (2009). WHO Guidelines on Hand Hygiene in Health Care. World Health Organization, Geneva, Switzerland.

\section{Cite this article as:}

Jemikalajah D. J., Enwa F. O. and Etaoghene A. D. 2021. Bacteriological Assessment of Palms of Students of Delta State University, Abraka. Nigerian Journal of Environmental Sciences and Technology, 5(1), pp. 234-239. https://doi.org/10.36263/nijest.2021.01.0276 